\title{
Who Shall Decide, When Doctors Disagree? David Leeson Responds in Turn
}

\section{David Leeson}

I don't have much to say to Robert M. Stein's response, except maybe this: I'm not entirely convinced that historians "have overwhelmingly relied on the protocols of nineteenth-century realistic fiction," as White and others have claimed. Over the last year, while teaching at Laurentian University, I conducted a seminar on topics in the history of nineteenth-century Europe, which included a four-week unit on the Franco-Prussian War and its impact on France. The structure of this unit was both chronological and historiographical. The first week was devoted to the war itself, and to the traditional military history thereof. The second week was devoted to the Paris Commune, and the social history of warfare. The third week was devoted to the popular memory of these conflicts during the period of the Third Republic, and the cultural history of warfare. The fourth week was devoted to Emile Zola's novel $L a$ Débâcle (1892), which I thought would help illuminate the previous three weeks' topics.

This was a fortunate choice: my students were quite enthusiastic about Zola's work. La Débâcle not only helped reinforce various points made by their historical readings: it made the conflict come alive. All of them agreed that the characters and events in the novel seemed real in ways that their historiographical counterparts did not. So if contemporary historians are indeed using the protocols of nineteenth-century realistic fiction, they're not using them very well. Having compared the two just recently, I have to say that I don't see much resemblance between them.

Let me now turn to Nancy Partner, who says I just don't understand Hayden White. White wasn't serious when he criticized historians for eschewing the literary techniques of Joyce, Yeats, and Ibsen, she says. He was just teasing. He was just making mischief. "One would think," she says, "that after some thirty years of the linguistic turn, historians might by now have learned to recognize rhetorical strategies for what they, rhetorically, are and not read earnest literal messages when mild shock tactics were intended."

Would one indeed? Partner does not support her claims with any proof: she just appeals to her own authority. So let's turn away from Hayden White's early essays, and examine what he says in his most recent collection, Figural Realism: Studies in the Mimesis Effect (1999). "Literary modernism did not repudiate narrative discourse but discovered in it a content, linguistic and tropological, adequate to the representations of dimensions of historical life only implicitly perceived in nineteenth-century realism," he says. "The ade- 
quacy of the 'content of the form' of literary modernism to the representation of both the form and the content of the kind of historical life we call modern argues for the relevance of literary modernism to a modern historical discourse." 1

He sounds fairly serious to me. Later, White argues that historians must write about "modernist events" like the Final Solution in modernist ways: "its representation, whether in history or in fiction, requires the kind of style, the modernist style, that was developed in order to represent the kind of experiences which social modernism made possible, the kind of style met with in a number of modernist writers...".2

Not much "teasing assertiveness" there. Still later, White even alludes to his 1966 manifesto when he writes:

What I am suggesting is that the stylistic innovations of modernism, born as they were of an effort to come to terms with the anticipated loss of the peculiar sense of history which modernism is ritually criticized for not possessing, may provide better instruments for representing modernist events (and premodernist events in which we have a typically modernist interest) than the storytelling techniques traditionally utilized by historians for the representation of the events of the past that are supposed to be crucial to the development of their communities' identity. Modernist techniques of representation provide the possibility of defetishizing both events and the fantasy accounts of them which deny the threat they pose in the very process of pretending to represent them realistically and clear the way for that process of mourning which alone can relieve the burden of history and make a more if not totally realistic perception of current problems possible. ${ }^{3}$

Unless Partner wants to say that White is just making mischief when he suggests that modernism can help console the bereaved, I would say that's case closed. But a skeptical reader may want more to convince them that White was in earnest. They may want the judgment of an expert: an expert like - Nancy Partner.

One of the works collected in The Content of the Form is a discussion of the work of Paul Ricoeur. In the course of this discussion, White remarks that "the very notion of a modernist historiography, modeled on the modernist, antinarrativist novel, would be in Ricoeur's estimation a contradiction in terms." 4 According to her own account, when she first read this, Partner didn't realize it was intended as a criticism. As a result, she was surprised to discover that White had been "rather scathing and dismissive of Paul Ricouer" in a published interview. "White apparently thinks that Ricoeur is too content with the tradi- 
tional literary instruments," she says, "too willing to celebrate narrative for its accomplishments, and in the end too committed to the western tradition of attempts to perfect the illusion of a true mimesis of time. Since Ricoeur virtually defines history as the human attempt to endow life with meaning and accepts that meaning, though not life, tends to come in story form, White seems to regard him as retrograde in both literary-historical and political ways." 5

But he shouldn't - at least he shouldn't, according to Nancy Partner. "White's own work does its work too well to encourage the attentive reader to look for anti-narrative, anti-formalist routes in some uncertain onward direction for history, toward an aesthetic epistemology more open to radical visions," she says.

The author's determination to strike out in that direction seems a committed but still a personal mission. His work doesn't lead there. As I read it, whether he approves or not, Hayden White's work stands in close affinity with that of Ricoeur, and reaches back to Aristotle of the Poetics, for primary questions about the confrontation of mind with world. This seems to me an interesting case of dissonance between authorial and textual intentions. ${ }^{6}$

I agree. What's more, I said as much myself. "It's not easy to square White's continuing enthusiasm for 'the kinds of antinarrative nonstories produced by literary modernism' with his own structuralist analysis of Western historiography" I said. "It's not easy to reconcile Hayden White's prescriptions for a meaningless history with his descriptions of history-writing," I said.

So, thank you, Doctor Partner: you've been very helpful. The witness is excused. The defence rests.

\section{Notes}

${ }^{1}$ Hayden White, "Literary Theory and Historical Writing," in Figural Realism: Studies in the Mimesis Effect (Baltimore: Johns Hopkins University Press, 1999), 26.

2 Hayden White, "Historical Emplotment and the Problem of Truth in Historical Representation," in Figural Realism, 42.

${ }^{3}$ Hayden White, "The Modernist Event," in Figural Realism, 82. On the previous page, White says: "it seems to me that the kinds of antinarrative nonstories produced by literary modernism offer the only prospect for adequate representations of the kind of 'unnatural' events - including the Holocaust - that mark our era and distinguish it absolutely from all the history that has come before it" [emphasis added]. 
${ }^{4}$ Hayden White, "The Metaphysics of Narrativity: Time and Symbol in Ricoeur's Philosophy of History," in The Content of the Form (Baltimore: Johns Hopkins University Press, 1987), 173.

${ }^{5}$ Nancy Partner, "Hayden White: The Form of the Content," History and Theory 37, 2 (May 1998), 169.

${ }^{6}$ Ibid.

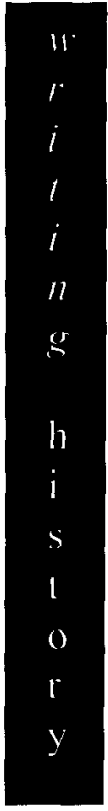

